\title{
O habitus autoritário das classes populares: um estudo com alunos do ensino médio de Juiz de Fora- MG' $^{1}$
}

\author{
Mariana Cardozo Batista de Oliveira ${ }^{2}$ \\ Recebido em novembro de 2019 \\ Aceito em dezembro de 2019
}

\section{RESUMO}

No âmbito da atual conjuntura política das sociedades ocidentais, é fato notório a ascensão do que se tem chamado na academia de "nova direita". Inspirada, pois, por esse fenômeno, objetivo contribuir para o estudo da relação entre juventude e conservadorismo/autoritarismo no Brasil. Para tanto, apliquei questionários em estudantes do ensino médio de quatro escolas de Juiz de Fora-MG, no intento de verificar a correlação entre determinados atributos de classe e a manifestação do autoritarismo. Algumas constatações importantes foram feitas, como, por exemplo, a observação de que as camadas populares são as que mais aderem a essa posição. Nesse sentido, os dados apontam que tais camadas são as mais autoritárias e, ao mesmo tempo, as mais despolitizadas, além de possuírem forte viés religioso, sobretudo evangélico. O estudo sinaliza, portanto, corroborar a hipótese principal, segundo a qual os capitais (econômico, cultural e social) acumulados pelos indivíduos estudados, na medida em que se apresentem em maior ou menor grau, possuem uma relação direta com a expressão de seu autoritarismo. Os resultados apresentados no presente trabalho foram obtidos a partir de correlações bivariadas entre as variáveis pesquisadas.

Palavras-chave: Autoritarismo; Conservadorismo; Classe; Juventude; Sociologia Política.

\section{ABSTRACT}

Within the current political conjuncture of western societies, the rise of what has been known in the academy as the "new right" is notorious. Thus inspired by this phenomenon, I aim to contribute for the study of the relationship between youthfulness and conservatism/authoritarianism in Brazil. For this, high school students from four schools in Juiz de Fora-MG were submitted to questionnaires, intending to explore the correlation between certain social class attributes and the manifestation of authoritarianism. Some important findings were made, such as the observation that the lower income layers are the ones that most adhere to this position. In this sense, the data indicates that these layers are the most authoritarian and, at the same time, the most depoliticized, besides having a strong religious bias, especially evangelical. The study, therefore, confirms the main hypothesis that the capital (financial, cultural and social) accrued by the individuals in the study, according to how it is presented in higher or lesser degrees, has a direct relation with the expression of their authoritarianism. The results presented in the present work were obtained from bivariate correlations between the researched variables.

Keywords: Authoritarianism; Conservatism; Class; Youthfulness; Political Sociology.

${ }^{1}$ Este trabalho foi apresentado no X Seminário Nacional Sociologia \& Política da UFPR (GT og - Intelectuais, marxismo e produção cultural: dilemas da esquerda latino-americana).

${ }^{2}$ Bacharel em Direito pela UFJF e Mestre em Ciências Sociais pelo PPGCSO/UFJF. E-mail: mariana.batistadeoliveira@gmail.com. Recebeu bolsa CAPES durante a realização do mestrado. 


\section{Introdução}

A temática abordada neste trabalho, fruto da pesquisa realizada durante meu mestrado em Ciências Sociais na Universidade Federal de Juiz de Fora, sob a orientação do Prof. Dr. Dmitri Cerboncini Fernandes, insere-se no campo da sociologia, tendo por interesse estudos que envolvam e relacionem autoritarismo, conservadorismo, classe social e juventudes.

É fato notório, quando se analisa a atual conjuntura política das sociedades ocidentais, o crescimento do autoritarismo e da intolerância em variados âmbitos sociais e correntes políticas, o que provocou a ascensão do que se tem chamado na academia de "nova direita"3.

Pensando especificamente no Brasil, o que é importante em razão das eleições que ocorreram em 2018, constatou-se, aqui, um fato específico que, acredito, ainda carece de explicações sociológicas mais satisfatórias: de acordo com pesquisas de opinião do Instituto Datafolha ${ }^{4}$, realizadas pouco antes das eleições, a maioria dos

3 A partir dos movimentos sociais de 2013 no Brasil, vários vetores, como produções intelectuais e acadêmicas, mídia, instituições e a opinião pública em geral, estão sinalizando para o surgimento de uma "nova direita" no país. Se antes, nos anos 1980/1990, se dizer de direita era algo mal visto e de cunho pejorativo, hodiernamente pode-se notar uma mudança nesse quadro, em que tal posicionamento se tornou motivo de orgulho e de defesa apaixonada para uma parcela da população. Antônio Flávio Pierucci, um dos teóricos pioneiros a conferir um olhar sociológico ao tema da adesão ao discurso da direita pelo eleitorado, já empregava, em estudos que realizou em São Paulo da década de 1980, a expressão "nova direita", uma vez que tais manifestações estavam se dando logo após o final da ditadura militar (em um período de redemocratização), tendo buscado apreender o que ela significava naquele momento, quais pautas defendia, o que não estava presente em seu discurso, quem eram os seus principais apoiadores, etc. Em um brevíssimo resumo, o autor conclui que o direitista paulistano daquela época era eminentemente branco, pertencia a uma classe média baixa que, apesar de apresentar algumas posses econômicas, era desprovida de capital cultural, e residia em bairros posicionados entre a periferia e o centro de São Paulo, localizados sobretudo nas zonas Norte e Leste da cidade, ou seja, distante das regiões que ofereciam serviços culturais (do outro lado da cidade); era uma direita estatista e moralista. Não se tratava, portanto, de fato, de uma "nova direita", e sim de uma direita velha ou transformada. Pode-se dizer que o mesmo se sucede atualmente. A direita hoje identificada uma vez mais como "nova" continua trazendo elementos dessa "velha direita", a despeito de modificações sociais e políticas que provocaram a adesão à discursos neoliberais (elemento praticamente ausente à época dos estudos de Pierucci) por parte de uma classe média que outrora reverberava algum progressismo político e cultural, de maneira que esta parcela, que vive do lado in da cidade, redefiniu o pertencimento à direita ao cultivar e apoiar essa guinada (FERNANDES e MESSENBERG, 2018).

4 Disponível em: <http://datafolha.folha.uol.com.br/eleicoes/2017/10/1923631-lula-lideradisputa-presidencial-sem-ele-marina-e-bolsonaro-ficam-a-frente.shtml>. Acesso em 13/10/2017. 
eleitores que indicavam voto em Jair Bolsonaro, político cujas pautas se inscrevem em um espectro de extrema-direita, eram jovens (tinham menos de 34 anos).

Desse modo, o objetivo geral da pesquisa é compreender por que uma parcela de jovens brasileiros vem apresentando cada vez mais tendências a adotar posições autoritárias, conservadoras ou até mesmo reacionárias ${ }^{5}$ na atual conjuntura, bem como os mecanismos causais desse processo, e verificar se a classe social é uma variável importante na ocorrência de tal fenômeno, de maneira a explicitar a relação entre juventude e conservadorismo/autoritarismo no Brasil.

Os estudos realizados sobre autoritarismo no Brasil, até agora, o fizeram, de maneira geral, sob um viés político, deixando de lado a análise sociológica. São também nesse sentido a maioria dos trabalhos que se dedicam a pensar a formação social do Brasil, os quais têm por foco o Estado, e não a sociedade civil, possuindo, além do mais, um caráter ensaísta, ou seja, não pautado em pesquisas científicas.

Nesse sentido, a sociologia, disciplina que poderia contribuir muito para a elucidação do fenômeno em tela, ainda não se debruçou de maneira sistemática sobre o mesmo, não havendo mais justificativas para que isso não seja feito. Uma perspectiva sociológica, portanto, se revela premente (FERNANDES e MESSENBERG, 2018).

5 Mannheim (1982), ao traçar uma diferenciação/aproximação entre tradicionalismo e conservantismo, aponta que o primeiro indicaria uma forma de conservantismo natural (mais ou menos universal; praticamente sem história verificável), enquanto o segundo seria tipicamente moderno (produzido por circunstâncias históricas e sociais particulares). O tradicionalismo, portanto, se aproximaria mais de uma tendência à reação original a deliberados impulsos reformistas e ao apego a modos de vida antigos, sendo "uma característica psicológica formal de todas as mentes individuais" (p. 108). A ação conservadora, contudo, é sempre dependente de uma série de circunstâncias concretas, que possui uma configuração estrutural objetiva, dinâmica, particular, política e historicamente desenvolvida. O autor afirma, ainda, que "o comportamento tradicionalista é quase que exclusivamente reativo" (p. 111), o que poderia aproximar o conceito do reacionarismo. Nesse sentido, enquanto o tradicionalismo seria uma tendência inconsciente que o indivíduo abriga em si mesmo, o conservantismo seria necessariamente consciente e reflexivo desde o início, uma vez que pretende fazer oposição a um movimento dotado de uma organização sistematicamente desenvolvida, o movimento progressista. Entretanto, a despeito das diferenciações possíveis, Mannheim pondera que "o conservantismo assume uma forma histórica particular de tradicionalismo e a leva até sua conclusão lógica" (p. 111), de maneira que os conceitos se sobrepõem; o conservantismo seria o tradicionalismo tornado consciente. $\mathrm{O}$ autor indica, ainda, que a ênfase sobre o concreto em oposição ao abstrato, aliado a outros impulsos fundamentais como a natureza qualitativa, a aceitação da realidade em oposição ao desejo progressista de mudança, a substituição do indivíduo atômico e das unidades aglomerativas como as classes por unidades sociais orgânicas, são as raízes do pensamento conservador. Por fim, Mannheim chama a atenção para o caráter relacional da formação de uma ideologia conservadora: "o conservantismo primeiro se torna consciente e reflexivo quando os outros modos de vida e pensamento aparecem em cena, contra os quais ele é compelido a tomar posição na batalha ideológica" (p. 132), como, por exemplo, o pensamento burguês-revolucionário e o pensamento baseado no direito natural. 


\title{
2. Metodologia, Referencial Teórico e Hipótese
}

\author{
Inspirando-me, sobretudo, na metodologia elaborada por Theodor W. Adorno
}

na obra $A$ Personalidade Autoritária ${ }^{6}$, apliquei 214 questionários em estudantes do ensino médio ${ }^{7}$ de quatro escolas de Juiz de Fora-MG (duas particulares e duas públicas estaduais - uma localizada no centro da cidade e outra na periferia), os quais buscavam medir a trajetória social dos participantes, seu nível socioeconômico, seus hábitos de consumo cultural (gosto) e suas opiniões políticas/morais, no intento de verificar a correlação entre determinados atributos de classe e a manifestação do autoritarismo.

${ }^{6}$ Os estudos sobre a Personalidade Autoritária empreendidos por Theodor W. Adorno e outros pesquisadores (psicólogos clínicos e sociais da Universidade da Califórnia em Berkeley), realizados nos Estados Unidos e publicados originalmente em 1950, foram motivados pelos acontecimentos históricos que envolveram a Europa no período que vai do começo da década de 1930 até o final da Segunda Grande Guerra, marcados pela influência de personalidades como a de Hitler e a de Mussolini na construção de sociedades autoritárias, e os desastres por elas causados. Tais estudos se debruçaram sobre os traços fascistas que podiam ser observados, de maneira explícita ou velada, nas modernas sociedades democráticas, tal como a norte-americana, e que poderiam estar latentes em cidadãos comuns, aqueles não participantes de organizações fascistas. Em sua pesquisa, Adorno et alli trabalharam com a hipótese principal de que as convicções econômicas, políticas e sociais de um indivíduo com frequência formam um padrão amplo e coerente, como se estivessem ligadas por uma "mentalidade" ou um "espírito", e esse padrão é a expressão de tendências profundas de sua personalidade. Sua preocupação maior foi com o indivíduo potencialmente fascista, aquele cuja estrutura é capaz de torná-lo particularmente suscetível à propaganda antidemocrática. Para empreender sua pesquisa e testar suas hipóteses, Adorno entendeu por bem realizar estudos de grupos conjuntamente a estudos com indivíduos, integrando ambos. Os indivíduos foram estudados através de técnicas clínicas especiais e entrevistas, de maneira a revelar seus desejos, medos e defesas latentes; os grupos foram estudados por meio de aplicação de questionários. Inicialmente, foram aplicados questionários anônimos a um grande grupo de estudantes universitários, os quais eram compostos por um bloco de questões factuais sobre a vida passada e presente do sujeito (a preferência e a prática religiosa, partidos políticos, profissão, salário, etc.), e um bloco contendo enunciados de conteúdos antidemocráticos variados, a fim de obter avaliações quantitativas de certas tendências ideológicas, com quais o participante deveria manifestar o grau de seu acordo ou desacordo (como antissemitismo, etnocentrismo e conservadorismo político-econômico). A partir das respostas a este questionário foi elaborada uma escala para mensurar as tendências antidemocráticas no seio da própria personalidade. Após, os indivíduos que se manifestaram mais de acordo com os enunciados, e, por contraste, também aqueles que demonstraram mais desacordo ou os mais neutros, foram estudados por meio de entrevistas e outras técnicas clínicas. Após essa primeira etapa, o questionário foi submetido a uma revisão e todo o procedimento descrito foi repetido. A entrevista foi utilizada, em parte, como uma forma de controle da validade do questionário, a fim de verificar se as pessoas que obtiveram as pontuações mais altas em termos de respostas antidemocráticas eram as mesmas que, frente a frente com um entrevistador, expressariam os mesmos sentimentos. Feito isso, o próximo passo foi traduzir essas manifestações em proposições para a reelaboração do questionário, o qual foi aplicado em um outro grupo de estudantes, a fim de encontrar indicações cada vez mais confiáveis sobre as forças centrais da personalidade e a relação destas com expressões antidemocráticas (ADORNO, 2007).

7 Os estudantes selecionados para participar da pesquisa integravam, à época da coleta dos dados (entre setembro e outubro de 2018), o segundo ou terceiro ano do ensino médio. A opção por este recorte se deu em razão de que, a partir do segundo ano, a maioria dos alunos já possui 16 anos ou mais, idade em que já estão aptos a serem eleitores. 
É importante destacar que, apesar de estar fazendo uma abordagem quantitativa dos dados coletados, não pretendo, com essa pesquisa, utilizar uma amostra representativa. Desse modo, não poderei fazer inferências estatísticas no sentido de uma amostra-população, uma vez que o número de observações não segue um critério amostral válido.

A aplicação dos questionários foi feita, simultaneamente, em todos os alunos da turma que se disponibilizaram a responder. Uma vez que as questões foram respondidas sem o auxílio de um aplicador para perguntar e anotar as respostas, algumas questões não foram respondidas, motivo pelo qual há alguns missings e nem sempre estarei trabalhando com exatos 214 indivíduos nas análises bivariadas.

Em termos estruturais, o questionário está organizado em três blocos: o primeiro se destina a apreender os dados socioeconômicos dos participantes, o segundo, seus hábitos de consumo cultural, e o terceiro, suas opiniões políticas e morais a respeito de temas como homossexualidade, programas sociais, machismo, movimentos sociais, punitivismo, imigração, racismo e meritocracia.

Ressalto que o presente trabalho irá reportar apenas algumas correlações bivariadas realizadas entre os dados socioeconômicos (primeiro bloco) e as opiniões políticas e morais dos respondentes (terceiro bloco), em razão da limitação do número de páginas ao qual está submetido.

Às alternativas das questões integrantes do terceiro bloco do questionário foram atribuídos diferentes pesos ou pontos, a depender do seu grau de autoritarismo/conservadorismo, de maneira que as respostas poderiam valer 1, 3, 6, 9 ou 12 pontos. Em seguida, a partir da soma dos valores referentes às respostas dos participantes para cada variável integrante deste bloco, foi elaborado um índice ${ }^{8}$, por meio do programa estatístico SPSS, que representa o nível de

${ }^{8}$ A elaboração deste índice foi inspirada em uma pesquisa desenvolvida no NUPPAI (Núcleo de Pesquisa "Preconceito, Autoritarismo e Ideologia"), coordenado pelo professor Dmitri Cerboncini Fernandes e vinculado ao PPGCSO/UFJF. Tal pesquisa, iniciada no ano de 2014, junto a discentes e docentes da Universidade Federal de Juiz de Fora, tem por objetivo apreender, sob uma perspectiva sociopsicanalítica, os mecanismos que permitem a instauração e a manutenção de discursos e atitudes enfeixados preliminarmente sob o conceito de "autoritários" na contemporaneidade. Por meio de aplicação de questionários e entrevistas em profundidade com agentes variados, o estudo pretende compreender os vínculos dos discursos e atitudes mencionados tanto com fontes heterônomas aos indivíduos quanto com suas trajetórias sociais. 
autoritarismo/conservadorismo de cada participante. Nesse sentido, quanto maior é a pontuação do participante, maior é o nível supracitado, e vice-versa. Feito isso, o próximo passo foi distribuir os indivíduos e as pontuações que obtiveram em quatro grupos homogêneos, classificados, em termos de seu autoritarismo, dentro das categorias "Menos", "Médio-", Médio+" e "Mais”, conforme Quadro 1, a seguir:

\section{Quadro 1 - Índice de Autoritarismo}

\begin{tabular}{|ll|r|r|r|r|}
\hline & $\begin{array}{c}\text { Frequênci } \\
\text { a }\end{array}$ & $\begin{array}{r}\text { Percentua } \\
\text { 1 }\end{array}$ & $\begin{array}{c}\text { Percentua } \\
\text { 1 Válido }\end{array}$ & $\begin{array}{r}\text { Percentual } \\
\text { Acumulado }\end{array}$ \\
\hline Índice & Menos & 55 & $25,7 \%$ & 25,7 & 25,7 \\
& Médio - & 52 & $24,3 \%$ & 24,3 & 50,0 \\
& Médio + & 55 & $25,7 \%$ & 25,7 & 75,7 \\
Mais & 52 & $24,3 \%$ & 24,3 & 100,0 \\
& Total & 214 & $100 \%$ & 100,0 & \\
\hline
\end{tabular}

Podemos notar que, dentro do universo pesquisado (214 estudantes), 55 estudantes foram classificados como "menos" autoritários, 52 como "médio-" autoritários, 55 como "médio +" autoritários e 52 como "mais" autoritários.

A elaboração desse índice foi fundamental para a análise bivariada dos dados, uma vez que, ao transformarmos as 21 questões de conteúdo político ou moral, integrantes do terceiro bloco do questionário, em apenas uma variável, denominada "Índice de Autoritarismo", nos foi possível correlacioná-la com outras variáveis constantes do instrumento de pesquisa, resultados estes que serão apresentados mais adiante.

É importante ressaltar que Adorno fez um estudo psicossocial para explicar posicionamentos autoritários de direita, tendo focado em algo interno ao sujeito, em sua estrutura de personalidade, em seus aspectos psicológicos. Não ignoro a importância desse tipo de estudo, tendo utilizado o modelo criado pelo autor para elaborar os instrumentos de pesquisa. Contudo, acredito que, para uma melhor compreensão do fenômeno objeto do presente estudo, é necessária, ainda, a contribuição de uma teoria de cunho sociológico, motivo pelo qual trabalhei, também, com os estudos de Pierre Bourdieu, notadamente na obra A Distinção: crítica social do julgamento, e sua teoria das classes sociais. 
A intenção é confrontar teorias psicanalíticas com teorias sociológicas, pois entendo que nem uma nem outra consegue explicar, por si só, o fenômeno do autoritarismo, ultrapassando-se, assim, a dicotomia clássica entre "indivíduo" e “sociedade".

Enquanto Adorno trabalha com o conceito de estrutura de personalidade, Bourdieu trabalha com a noção de habitus para explicar a posição, a disposição e a tomada de posição dos agentes dentro da estrutura social.

Segundo Bourdieu (2015), os pontos de vista dos agentes, dentro do espaço social $^{10}$, dependem da posição aí ocupada por eles, e se referem a sua vontade de conservá-lo ou de transformá-lo.

A construção do habitus é, então, uma fórmula geradora que permite relacionar as características pertencentes às condições econômica e social dos agentes (o volume e a estrutura do capital) e os traços distintivos relacionados à posição ocupada por eles no espaço dos estilos de vida; é, ainda, uma necessidade incorporada, convertida em disposição geral e operadora de práticas sistemáticas, por ser o produto da aplicação de esquemas idênticos e, ao mesmo tempo, diferentes das práticas características de outros estilos de vida. Percebe-se, portanto, que distintas condições de existência produzem habitus distintos (BOURDIEU, 2015).

Vinculado à noção de habitus, outro componente importante para a compreensão da teoria bourdieusiana é a noção de classe ou fração de classe. Uma classe ou uma fração de classe não é caracterizada unicamente pela posição dos agentes que a ela pertencem nas relações de produção (por profissão, renda ou nível de instrução), mas também pela proporção entre o número de homens e mulheres distribuída em determinado espaço geográfico, e por outras características auxiliares, como, por exemplo, filiação étnica (BOURDIEU, 2015).

Nesse sentido, a classe social não se define apenas por uma propriedade, nem mesmo pela mais determinante delas, que é o volume e a estrutura do capital, e nem

10 "O espaço social (...) é uma representação abstrata, produzida mediante um trabalho específico de construção e, à maneira de um mapa, proporciona uma visão panorâmica, um ponto de vista sobre o conjunto dos pontos a partir dos quais os agentes comuns (...) lançam seu olhar sobre o mundo social" (BOURDIEU, 2015, p. 162). 
por uma soma de propriedades, como o sexo, a idade ou a origem étnica, mas sim pela relação entre todas as propriedades pertinentes (BOURDIEU, 2015).

Portanto, seguindo pistas de uma sociologia política embasada, sobretudo, nos achados de Pierre Bourdieu (2015) e em sua teoria das classes sociais, defendo a hipótese de que os capitais (econômico, cultural e social) acumulados pelos indivíduos estudados, na medida em que se apresentem em maior ou menor grau, possuem uma relação direta com o fato de eles revelarem ou não tendências a adotar posições autoritárias, conservadoras ou reacionárias. Há uma possível relação inversa entre maior capital cultural e maior tendência ao autoritarismo, ou seja, quanto mais capital cultural o indivíduo deter, menor será a sua tendência a adotar posições autoritárias e conservadoras sob o aspecto moral, ou seja, menor será a tendência de que ele vote à direita.

Nesse sentido foram as conclusões do autor ao analisar os resultados de pesquisas de opinião realizadas na França pelos institutos SOFRES e IFOP entre 1959 e 1972. Segundo Bourdieu (2015), ao responderem as pesquisas de opinião, os agentes mais desprovidos do ponto de vista político, os quais, em sua maioria, também são os mais desprovidos do ponto de vista econômico e cultural, aplicam a questões políticas esquemas de apreciação e percepção que levam a constatação de seu autoritarismo e conservadorismo. Ao reconhecerem na pergunta a ser respondida ao instituto de sondagem uma forma particular de conservação ou subversão da ordem estabelecida, tais agentes não respondem à questão que, de fato, lhes é formulada, mas a uma pergunta que elaboram com seus próprios recursos, isto é, a partir dos princípios que orientam seu ethos de classe.

A partir desta base teórica, a elaboração dos instrumentos de pesquisa (questionário e roteiro de entrevista) foi pensada de modo a apreender os volumes de capital (cultural, econômico e social) acumulados pelos indivíduos participantes, além de outros atributos como cor/etnia, sexo, religião, e relacioná-los com suas opiniões políticas e morais a respeito de variados temas, no intuito de compreendermos a ligação existente entre habitus de classe e posicionamento político e moral dentro do universo estudado. A seguir, serão apresentados alguns resultados destas correlações. 


\section{Resultados}

Nesta seção irei apresentar alguns resultados obtidos das análises dos dados com o auxílio do programa estatístico SPSS, os quais se referem, sobretudo, ao cruzamento de algumas variáveis socioeconômicas com as escolas pesquisadas e com a variável "índice de autoritarismo”.

\subsection{A cidade ${ }^{11}$}

Juiz de Fora, cidade na qual encontram-se as escolas e, por consequência, os indivíduos pesquisados, é um município localizado na Zona da Mata (sudeste) do estado de Minas Gerais. No último censo, realizado no ano de 2010, contava com 516.247 habitantes e uma densidade demográfica de 359,59 hab $/ \mathrm{km}^{2}$, sendo, à época, a $4^{\underline{a}}$ maior cidade do estado e a $36^{\underline{a}}$ maior do país.

Em termos educacionais, no ano de 2017, o município contava com 59.774 estudantes matriculados no ensino fundamental e 18.947 no ensino médio. Destes últimos, universo que nos interessa no presente trabalho, 12.966 matrículas eram em escolas públicas estaduais, 1.357, em escolas públicas federais, e 4.624 em escolas privadas.

\subsection{Apresentando as escolas pesquisadas}

Apliquei, ao todo, 214 questionários em alunos dos segundo e terceiro ano do ensino médio de quatro escolas de Juiz de Fora, sendo duas públicas estaduais e duas particulares, conforme Quadro 2:

\section{Quadro 2 - Quantidade de alunos entrevistados por Escola}

\begin{tabular}{|c|r|r|r|r|}
\hline Escola & $\begin{array}{c}\text { Frequênci } \\
\text { a }\end{array}$ & $\begin{array}{r}\text { Percentua } \\
\mathbf{1}\end{array}$ & $\begin{array}{c}\text { Percentua } \\
\text { 1 Válido }\end{array}$ & $\begin{array}{r}\text { Percentual } \\
\text { Acumulado }\end{array}$ \\
\hline Escola 1 & 47 & $22 \%$ & 22,0 & 22,0 \\
Escola 2 & 36 & $16,8 \%$ & 16,8 & 38,8 \\
\hline
\end{tabular}

\footnotetext{
Informações obtidas no site do IBGE. Disponível em https://cidades.ibge.gov.br/brasil/mg/juiz-de-fora/panorama. Acesso em: 23/04/2019.
} 


\begin{tabular}{|l|r|r|r|r|}
\hline Escola 3 & 104 & $48,6 \%$ & 48,6 & 87,4 \\
Escola 4 & 27 & $12,6 \%$ & 12,6 & 100,0 \\
Total & 214 & $100 \%$ & 100,0 & \\
\hline
\end{tabular}

1) Escola 1: trata-se de escola pública estadual localizada na periferia da cidade, em dois bairros localizados a $10 \mathrm{~km}$ e $15 \mathrm{~km}$ do centro, respectivamente. Nesta escola, apliquei 57 questionários, o que representa $22 \%$ do universo.

2) Escola 2 - escola privada localizada no centro da cidade. Nesta escola, apliquei 36 questionários, o que representa $16,8 \%$ do universo.

3) Escola 3 - escola pública estadual localizada no centro da cidade. Nesta escola, apliquei 104 questionários, o que representa $48,6 \%$ do universo.

4) Escola 4 - escola privada localizada em bairro a $3 \mathrm{~km}$ do centro da cidade. Nesta escola, apliquei 27 questionários, o que representa 12,6\% do universo.

Acredito que a melhor forma de apresentar as escolas em relação ao nível socioeconômico de seus alunos ${ }^{12}$ é através da comparação entre elas. Portanto, farei uma análise conjunta e simultânea de todas as escolas. Trabalharei, aqui, com as variáveis, cor, renda familiar, escolaridade e profissão dos responsáveis dos alunos ${ }^{13}$, de acordo com os quadros apresentados a seguir ${ }^{14}$.

\section{Quadro 3 - Escolas x Cor (210 respondentes)}

\begin{tabular}{|ll|r|r|r|r|r|}
\hline & & \multicolumn{4}{|c|}{ Escola } & \multirow{2}{*}{ Total } \\
\cline { 3 - 7 } & & Escola 1 & Escola 2 & Escola 3 & Escola 4 & Tespondente \\
Cor & Branca & 16 & 28 & 46 & 21 & 111 \\
\hline
\end{tabular}

${ }_{12}$ As configurações das escolas foram elaboradas em termos proporcionais e considerando apenas o os alunos do universo pesquisado, e não o total de alunos da escola.

13 Antes de descrever os quadros, uma breve explicação sobre o critério de categorização das profissões é importante. O critério “manual não qualificado" representa as profissões que não necessitam de uma qualificação para serem exercidas, como, por exemplo, empregada doméstica, porteiro, pedreiro, etc. O critério "manual qualificado" diz respeito a profissões que não necessitam de curso superior para serem exercidas, mas que implicam em alguma qualificação, como motorista, secretária, policial militar, etc. O critério “curso técnico e graduação" representa as profissões que necessitam de curso técnico ou de algum curso superior para serem exercidas, mas que não se encaixam nos critérios "superior econômico" ou "superior cultural". Esses dois últimos critérios referem-se, respectivamente, às profissões mais historicamente valorizadas economicamente na sociedade, como medicina, direito e engenharia, e às profissões que detêm mais capital cultural, como a de professor. É importante destacar, também, que as categorizações das profissões dos responsáveis foram realizadas em conjunto com a variável "escolaridade" dos mesmos.

14 Para apreender as informações acerca do universo como um todo, observar os percentuais nos quais as linhas somam $\mathbf{1 0 0} \%$ e, para apreender as informações acerca das escolas, observar os percentuais nos quais as colunas somam $100 \%$. 
Quadro 4 - Escolas x Renda Familiar (209 respondentes)

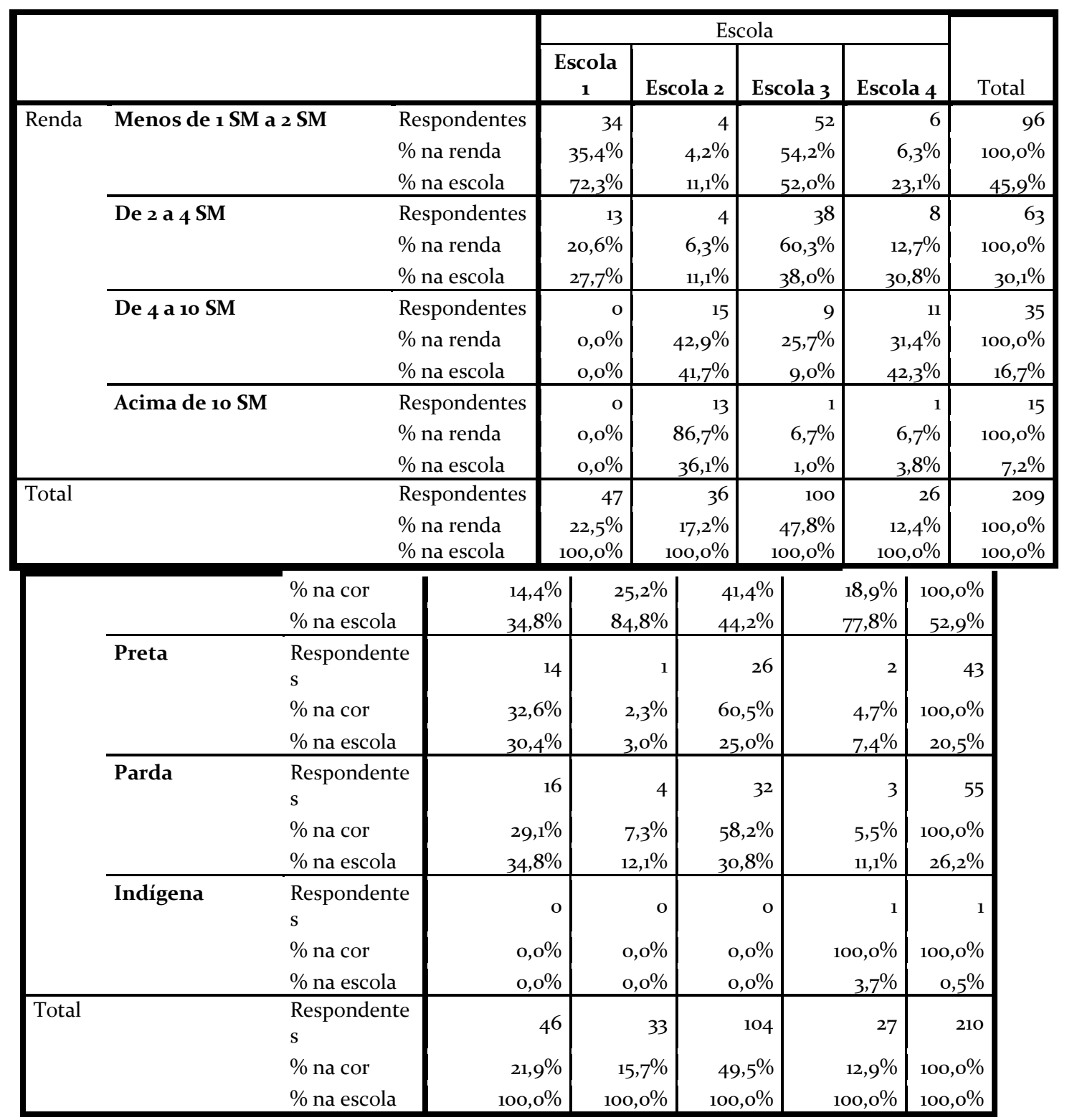




\section{Quadro 5 - Escolas x Escolaridade do Responsável de Sexo Feminino (196 respondentes)}

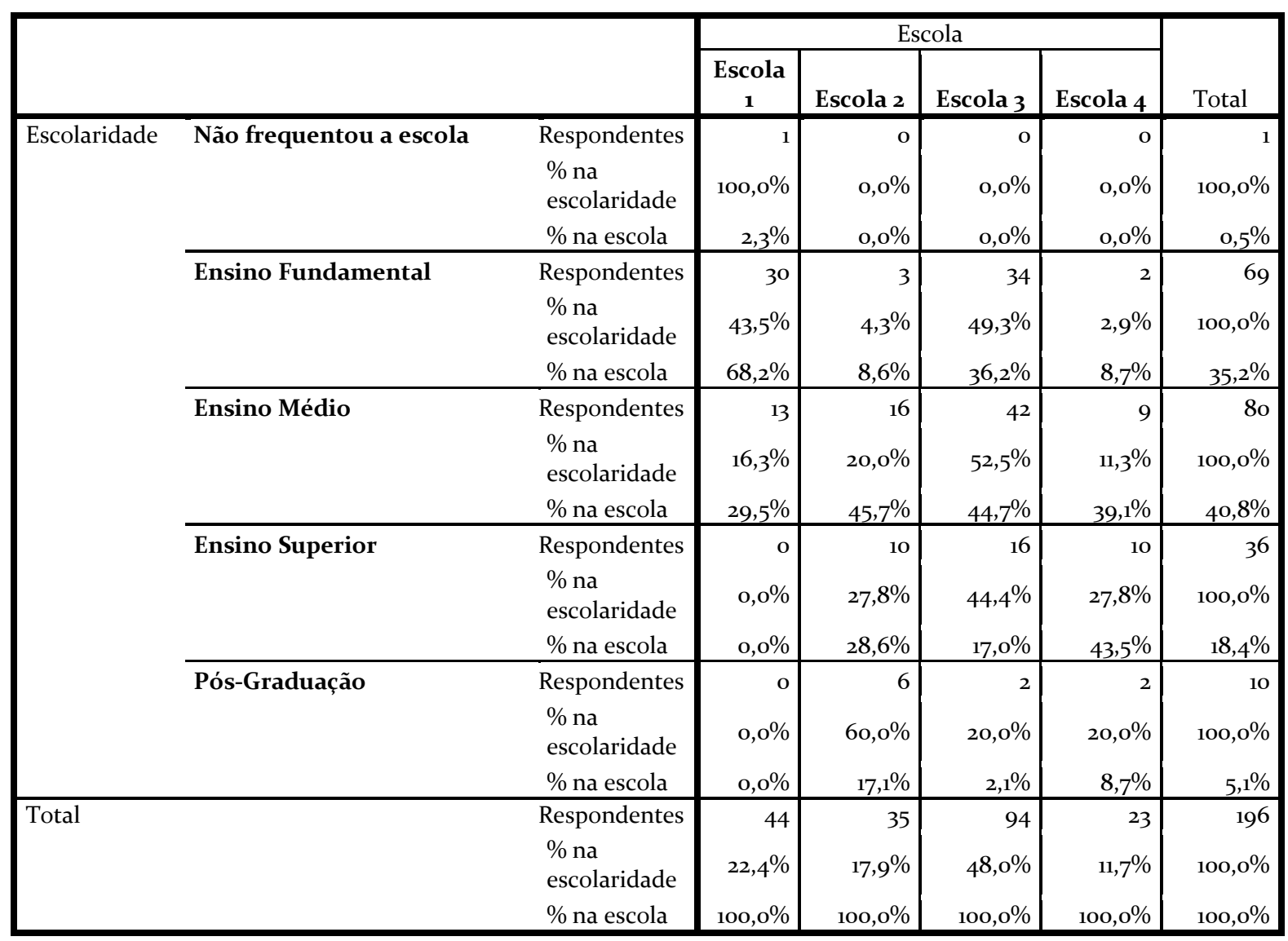

\section{Quadro 6 - Escolas x Escolaridade do Responsável de Sexo Masculino (171 respondentes)}

\begin{tabular}{|c|c|c|c|c|c|c|c|}
\hline & & & \multicolumn{4}{|c|}{ Escola } & \multirow[b]{2}{*}{ Total } \\
\hline & & & $\begin{array}{c}\text { Escola } \\
1\end{array}$ & Escola 2 & Escola 3 & Escola 4 & \\
\hline \multirow[t]{8}{*}{ Escolaridade } & \multirow[t]{3}{*}{ Não frequentou a escola } & Respondentes & o & o & o & 1 & 1 \\
\hline & & $\begin{array}{l}\% \text { na } \\
\text { escolaridade }\end{array}$ & $0,0 \%$ & $\mathrm{o}, \mathrm{o} \%$ & $0,0 \%$ & $100,0 \%$ & $100,0 \%$ \\
\hline & & $\%$ na escola & $\mathrm{o}, \mathrm{o} \%$ & $0,0 \%$ & $0,0 \%$ & $5,0 \%$ & $0,6 \%$ \\
\hline & \multirow[t]{3}{*}{ Ensino Fundamental } & Respondentes & 22 & 3 & 34 & 2 & 61 \\
\hline & & $\begin{array}{l}\% \text { na } \\
\text { escolaridade }\end{array}$ & $36,1 \%$ & $4,9 \%$ & $55,7 \%$ & $3,3 \%$ & $100,0 \%$ \\
\hline & & $\%$ na escola & $64,7 \%$ & $9,7 \%$ & $39,5 \%$ & $10,0 \%$ & $35,7 \%$ \\
\hline & \multirow[t]{2}{*}{ Ensino Médio } & Respondentes & 12 & 15 & 40 & 9 & 76 \\
\hline & & $\begin{array}{l}\% \text { na } \\
\text { escolaridade }\end{array}$ & $15,8 \%$ & $19,7 \%$ & $52,6 \%$ & $11,8 \%$ & $100,0 \%$ \\
\hline
\end{tabular}




\begin{tabular}{|c|c|c|c|c|c|c|c|}
\hline & & $\%$ na escola & $35,3 \%$ & $48,4 \%$ & $46,5 \%$ & $45,0 \%$ & $44,4 \%$ \\
\hline & Ensino Superior & Respondentes & o & 10 & 9 & 4 & 23 \\
\hline & & $\begin{array}{l}\% \text { na } \\
\text { escolaridade }\end{array}$ & $0,0 \%$ & $43,5 \%$ & $39,1 \%$ & $17,4 \%$ & $100,0 \%$ \\
\hline & & $\%$ na escola & $0,0 \%$ & $32,3 \%$ & $10,5 \%$ & $20,0 \%$ & $13,5 \%$ \\
\hline & Pós-Graduação & Respondentes & o & 3 & 3 & 4 & 10 \\
\hline & & $\begin{array}{l}\% \text { na } \\
\text { escolaridade }\end{array}$ & $0,0 \%$ & $30,0 \%$ & $30,0 \%$ & $40,0 \%$ & $100,0 \%$ \\
\hline & & $\%$ na escola & $0,0 \%$ & $9,7 \%$ & $3,5 \%$ & $20,0 \%$ & $5,8 \%$ \\
\hline Total & & Respondentes & 34 & 31 & 86 & 20 & 171 \\
\hline & & $\begin{array}{l}\% \text { na } \\
\text { escolaridade }\end{array}$ & $19,9 \%$ & $18,1 \%$ & $50,3 \%$ & $11,7 \%$ & $100,0 \%$ \\
\hline & & $\%$ na escola & $100,0 \%$ & $100,0 \%$ & $100,0 \%$ & $100,0 \%$ & $100,0 \%$ \\
\hline
\end{tabular}

\section{Quadro 7 - Escolas X Profissão do Responsável Feminino (202 respondentes)}

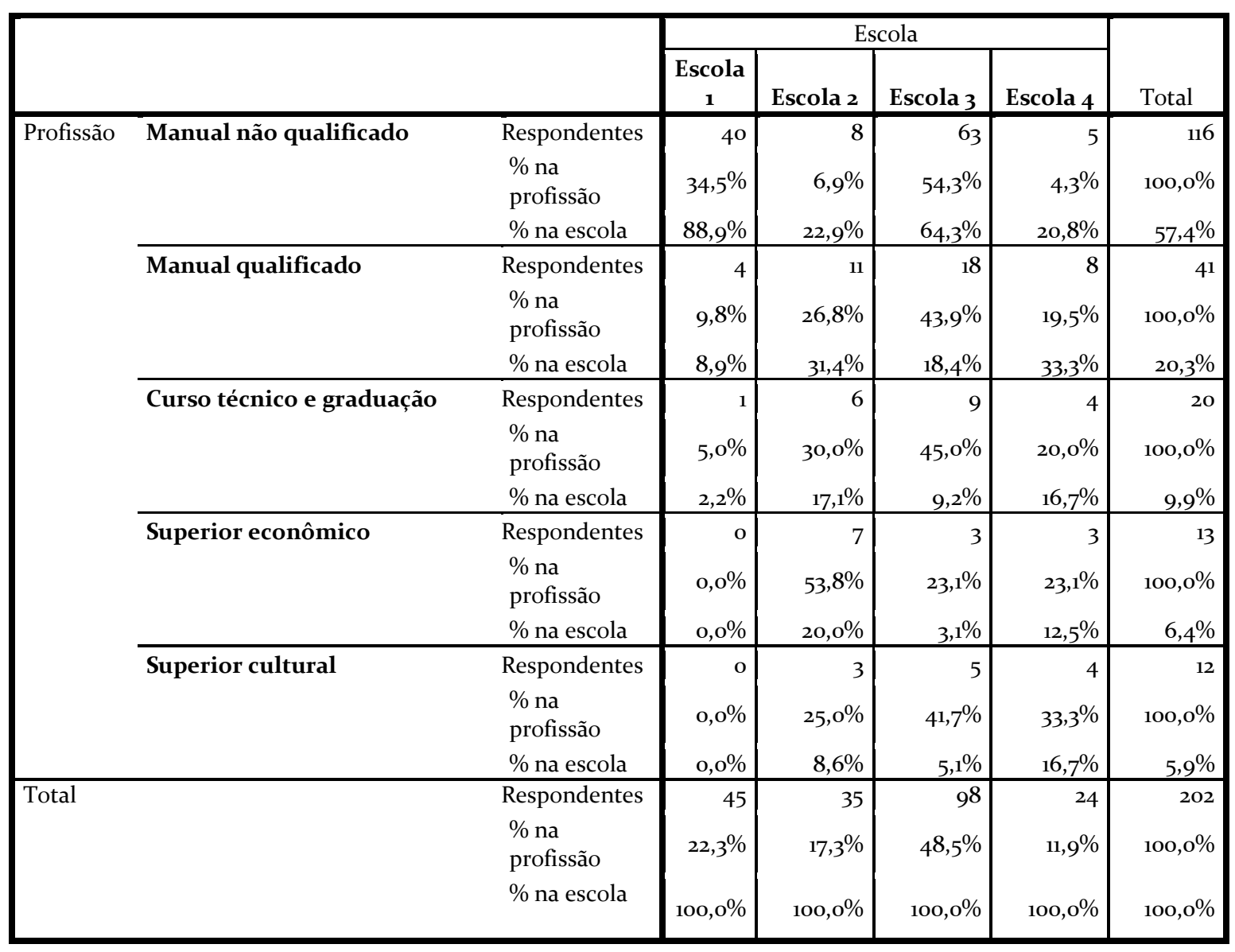


Quadro 8 - Escolas X Profissão do Responsável Masculino (182 respondentes)

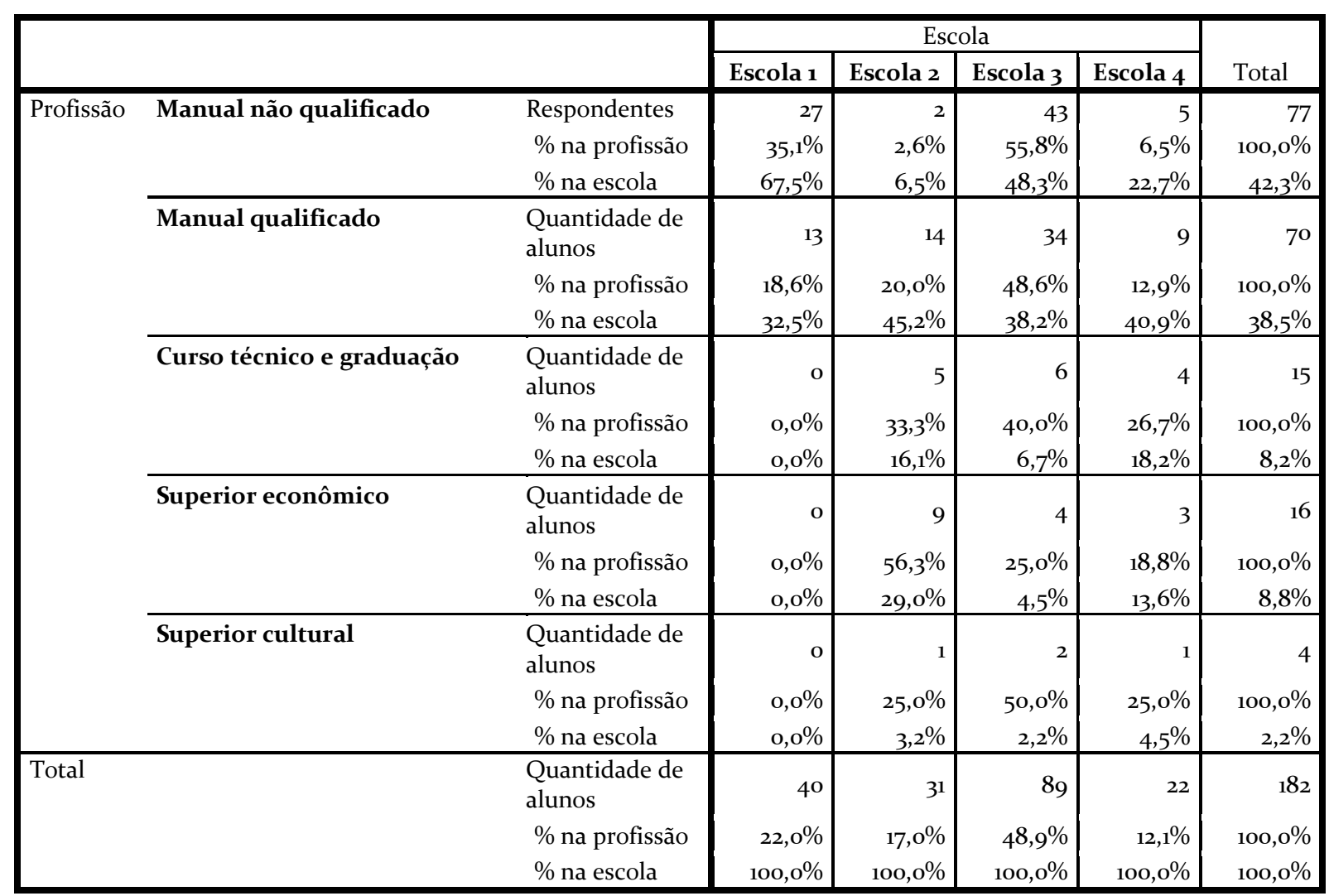

Conforme podemos perceber a partir da análise dos quadros apresentados, a Escola 1 é bastante homogênea em termos socioeconômicos, apresentando a seguinte configuração em relação aos seus alunos:

65,2\% deles são pretos ou pardos (Quadro 3); 100\% deles estão concentrados nas duas primeiras faixas de renda familiar (menos de 1 SM a 2 SM e de 2 a 4 SM), sendo que 72,3\% estão localizados na primeira faixa (Quadro 4); em termos escolaridade dos responsáveis, não há nenhum cujo responsável do sexo feminino ou masculino tenha ensino superior ou pós-graduação, incompletos ou completos, de modo que a maioria deles está concentrada no critério "ensino fundamental" (completo ou incompleto) - 68,2\% e 64,7\%, respectivamente (Quadros 5 e 6); e, consequentemente, em termos de profissão dos responsáveis, não há nenhum cujo responsável do sexo feminino ou masculino esteja posicionado nos critérios "superior econômico" ou "superior cultural", estando a maioria deles posicionada no critério manual não qualificado - 88,9\% e 67,5\%, respectivamente (Quadros 7 e 8). Podemos 
notar que os alunos desta escola são, de modo geral, mais escolarizados que os seus pais.

Trata-se, portanto, da escola, entre as 4 pesquisadas, cujos alunos possuem os menores níveis de capital econômico e cultural acumulados. Penso que isso se justifique pela sua localização, o que a faz receber os alunos que moram na periferia da cidade.

Continuando as análises das escolas públicas, a Escola 3 se apresenta mais heterogênea que a Escola 1 em termos socioeconômicos, o que acredito que ocorra, também, em razão da sua localização. Por estar posicionada no centro da cidade, a mesma recebe estudantes majoritariamente provenientes de bairros próximos ao centro ou que residem na região central.

Tal escola apresenta a seguinte configuração em relação aos seus alunos: os pretos e pardos ainda são a maioria, representando 55,8\% do total de respondentes, contudo, possui uma porcentagem considerável de alunos brancos - 44,2\% (Quadro 3); 90\% deles estão concentrados nas duas primeiras faixas de renda familiar (menos de 1 SM a 2 SM e de 2 a 4 SM), contudo, 38\% estão na segunda faixa, número bastante superior ao da outra escola pública (Quadro 4); em termos de escolaridade dos responsáveis, apesar de a maioria dos responsáveis do sexo feminino ou masculino possuir ensino fundamental (36,2\% e 39,5 respectivamente) ou ensino médio $(44,7 \%$ e $46,5 \%$ ), incompletos ou completos, podemos notar que os mesmos são mais escolarizados que os responsáveis dos alunos da Escola 1, de maneira que alguns possuem, ainda, nível superior (17\% e 10,5\% respectivamente) ou pós-graduação (2,1\% e 3,5\% respectivamente), completos ou incompletos (Quadros 5 e 6); e em termos de profissão dos responsáveis do sexo feminino e masculino, a maioria também é constituída por "manuais não qualificados" (64,3\% e 48,3\% respectivamente) e "manuais qualificados" (18,4\% e 38,2\%), contudo, ainda que em menor número, há representantes das outras categorias, fato que estava ausente na Escola 1 (Quadros 7 e 8).

Podemos perceber, portanto, que a Escola 3 possui alunos com uma maior variação nos índices socioeconômicos em comparação com Escola 1, o que a torna mais heterogênea. 
É importante destacar, ainda, que a Escola 3 é a que concentra a maior parte dos casos pesquisados (104 alunos ou 48,6\% do universo). Apesar de representar quase metade da amostra, acredito que, em razão do seu caráter heterogêneo, isso não representa um problema para a pesquisa.

Passando, agora, para a análise das escolas particulares, a Escola 2, dentre elas, é a mais homogênea em termos socioeconômicos, apresentando a seguinte configuração em relação aos seus alunos:

84,8\% deles são brancos (Quadro 3); 77,8\% deles estão concentrados nas duas últimas faixas de renda familiar (de 4 a 10 SM e acima de 10 SM) (Quadro 4); em termos escolaridade dos responsáveis do sexo feminino ou masculino, 45,7\% e 42\%, respectivamente, possuem ensino superior ou pós-graduação, incompletos ou completos (Quadros 5 e 6); e, em termos de profissão dos responsáveis do sexo feminino e masculino, $45,7 \%$ e $48,3 \%$, respectivamente, possuem curso técnico, curso superior, profissões superiores economicamente ou profissões superiores culturalmente, sendo esta a escola que mais possui alunos cujos pais ocupam profissões de cunho "superior econômico" - 20\% e 29\%, respectivamente (Quadros 7 e $8)$.

A Escola 2, em comparação com todas as escolas, é a que apresenta alunos com os maiores níveis de capital econômico acumulados.

Por fim, passemos para a análise da Escola 4, a qual, em termos comparativos com a Escola 2, apresenta uma composição mais heterogênea de alunos. Contudo, sua heterogeneidade não é tão expressiva em relação à Escola 2 como a Escola 3 é em relação à Escola 1.

A Escola 4 apresenta a seguinte configuração no que tange aos seus alunos: 77,8\% deles são brancos, percentual menor do que o número de brancos na Escola 2 (Quadro 3); 73,1\% deles estão concentrados nas faixas de renda intermediárias (de 2 a 4 SM e de 2 a 4 SM), possuindo, portanto, um nível de renda um pouco menor que os alunos da outra escola particular (Quadro 4); em termos de escolaridade dos responsáveis do sexo feminino e masculino, 52,2\% e 40\%, respectivamente, possuem ensino superior ou pós-graduação, incompletos ou completos (Quadros 5 e 6); e em termos de profissão dos responsáveis do sexo feminino e masculino, 45,9\% e 36,3\%, 
respectivamente, possuem curso técnico, curso superior, profissões superiores economicamente ou profissões superiores culturalmente. Apesar de estes serem números altos em relação aos encontrados nas escolas públicas, a Escola 4 possui um valor expressivo de alunos cujos responsáveis do sexo feminino e masculino realizam profissões de cunho "manual qualificado" - 33,3\% e 40,9\%, respectivamente. Ademais, tal escola é a que mais possui alunos cujos responsáveis ocupam profissões de cunho “superior cultural" - 16,7\% (feminino) e 4,5\%, (masculino) (Quadros 7 e 8).

Feita a apresentação socioeconômica das escolas pesquisadas, passarei, agora, para a correlação entre algumas variáveis e o índice de autoritarismo.

\subsection{O Índice de Autoritarismo ${ }^{15}$.}

Nesta seção, selecionarei algumas variáveis como sexo, renda, religião, candidatos e escolas para uma correlação com a variável "índice de autoritarismo" 16 .

Primeiramente, vejamos a relação entre o índice e a variável sexo dos respondentes (Quadro 9):

\section{Quadro 9 - Índice de Autoritarismo X Sexo (214 respondentes)}

\begin{tabular}{|lll|r|r|r|r|}
\hline & & \multicolumn{3}{|c|}{ Índice de Autoritarismo } & \multirow{2}{*}{ Total } \\
\cline { 3 - 6 } & Masculino & Respondentes & Médio - & Médio + & Mais & Tot \\
& \% no sexo & 11 & 21 & 25 & 25 & 82 \\
& & $13,4 \%$ & $25,6 \%$ & $30,5 \%$ & $30,5 \%$ & $100,0 \%$
\end{tabular}

15 Para uma correta leitura dos quadros apresentados, observar que os resultados referentes ao universo como um todo encontram-se nos percentuais de linha (que somam 100\%) e que os resultados referentes às categorias do índice de autoritarismo encontram-se nos percentuais de coluna (que somam 100\%). Desse modo, a título de exemplo, no Quadro 9, 13,4\% dos respondentes que foram classificados como "menos" autoritários são do sexo masculino e $20 \%$ dos respondentes de sexo masculino foram considerados "menos" autoritários.

${ }^{16}$ As correlações apresentadas levam em consideração um valor de significância menor que 0,05 (teste qui-quadrado de Pearson) para rejeitar a hipótese nula, ou seja, para demonstrar que as variáveis correlacionadas não são independentes. Contudo, em casos em que este valor seja superior a 0,05, não significa que as mesmas são completamente independentes, mas apenas que se relacionam de uma maneira menos forte. (EVERITT, 1991). Nesse sentido, Bourdieu (2006 apud KLÜGER, 2018) afirma ser problemático atribuir independência a variáveis que são sempre imbricadas e multideterminadas, de modo que a mais independente das variáveis oculta uma rede de relações "presente, subterraneamente, na relação que ela mantém com uma determinada opinião ou prática” (p. 81). 


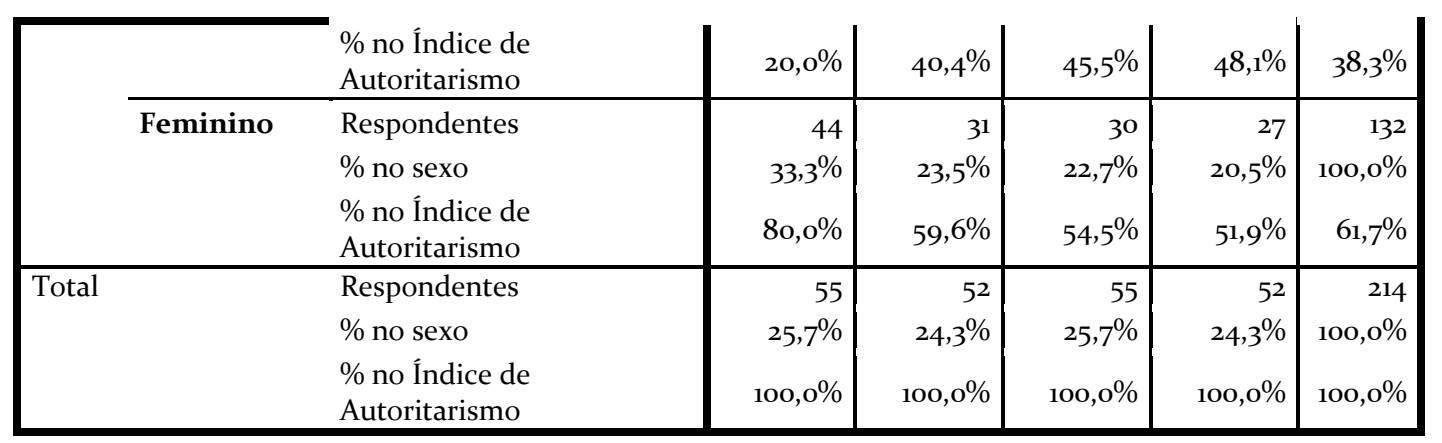

*Significância: o,o19.

Podemos observar que os respondentes de sexo masculino são mais autoritários que as de sexo feminino. Enquanto os primeiros estão localizados de forma majoritária entre as categorias "médio+" e "mais" (61\%), as segundas encontram sua maior representação nas categorias "menos" e "médio-" (56,8\%). Ademais, 80\% dos respondentes que foram considerados "menos" autoritários são do sexo feminino.

No que toca à correlação do índice com a variável renda familiar (Quadro 10), temos os seguintes resultados:

\section{Quadro 10 - Índice de Autoritarismo X Renda Familiar (209 respondentes)}

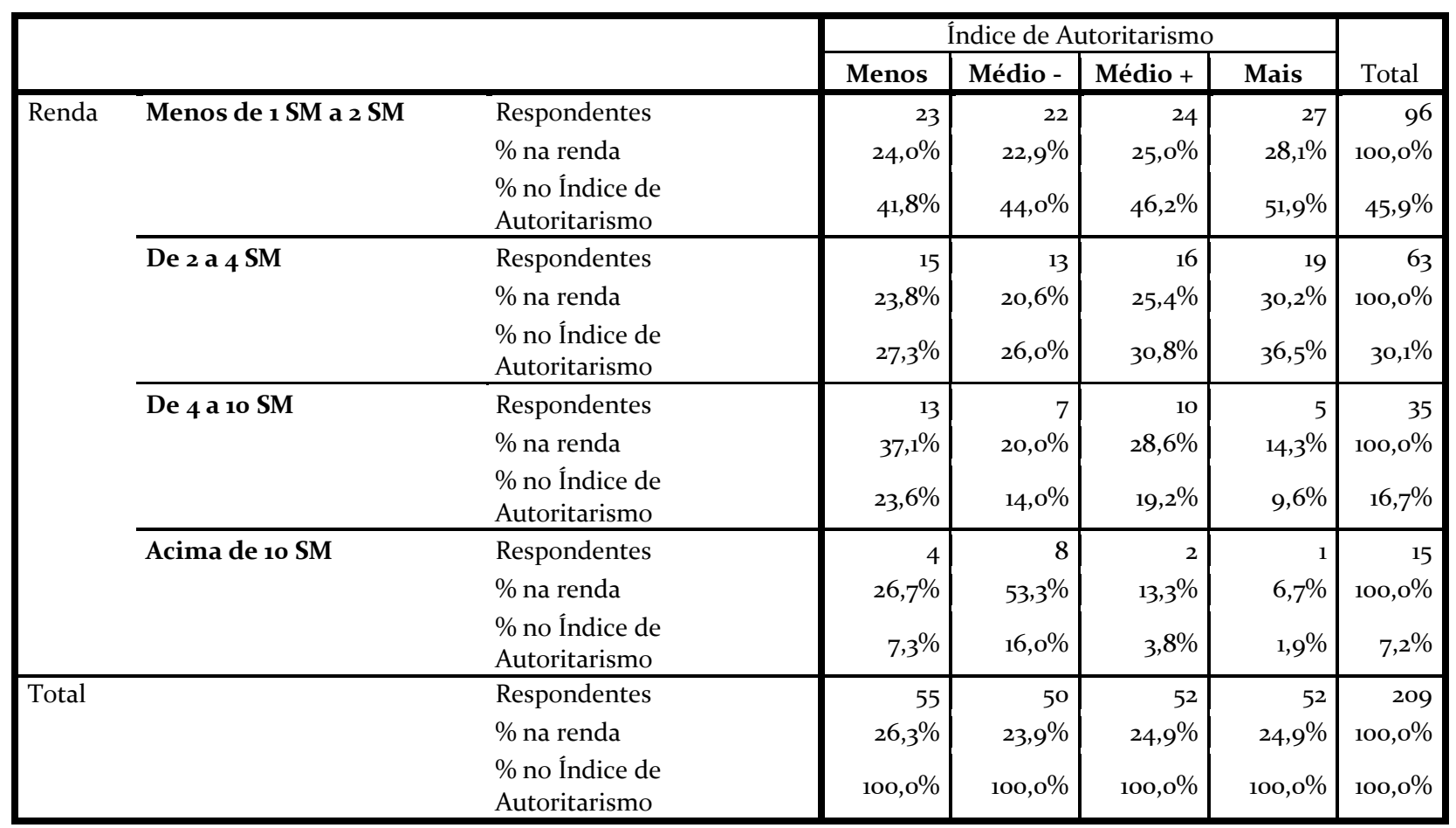

\footnotetext{
*Significância: o,ooo
} 
Podemos observar que, considerando as categorias extremas da renda familiar, a primeira (menos de 1 SM a 2 SM) concentra majoritariamente os respondentes enquadrados nos níveis "médio+" e "mais" autoritários (53,1\%), enquanto a última (acima de $10 \mathrm{SM}$ ) engloba a maioria dos enquadrados nos níveis "menos" e "médio-" autoritários $(80 \%)$. Ademais, ao considerarmos os respondentes "médio+" e "mais" autoritários, observamos que eles se localizam, em sua maioria, nas duas primeiras faixas de renda (menos de $1 \mathrm{SM}$ a 2 SM e de 2 a $4 \mathrm{SM}$ ) - 77,8\% e 88,4\%, respectivamente.

Por outro lado, ao analisarmos a relação dos respondentes "menos" e médio-" autoritários com as duas últimas faixas de renda (de 4 a $10 \mathrm{SM}$ e acima de $10 \mathrm{SM}$ ), podemos notar que eles são maioria em relação aos "médios+" e os "mais" autoritários - 30,9\% (menos) e 30\% (médio-) contra 23\% (médio+) e 11,5\% (mais).

Concluímos, portanto, que, dentro do universo pesquisado, as pessoas de renda familiar mais baixa são as que mais tendem a adotar posições autoritárias em termos políticos e conservadoras em termos morais.

Passemos, agora, para a correlação entre o "índice de autoritarismo" e a religião dos respondentes (Quadro 11).

\section{Quadro 11 - Índice de Autoritarismo X Religião (211 respondentes)}

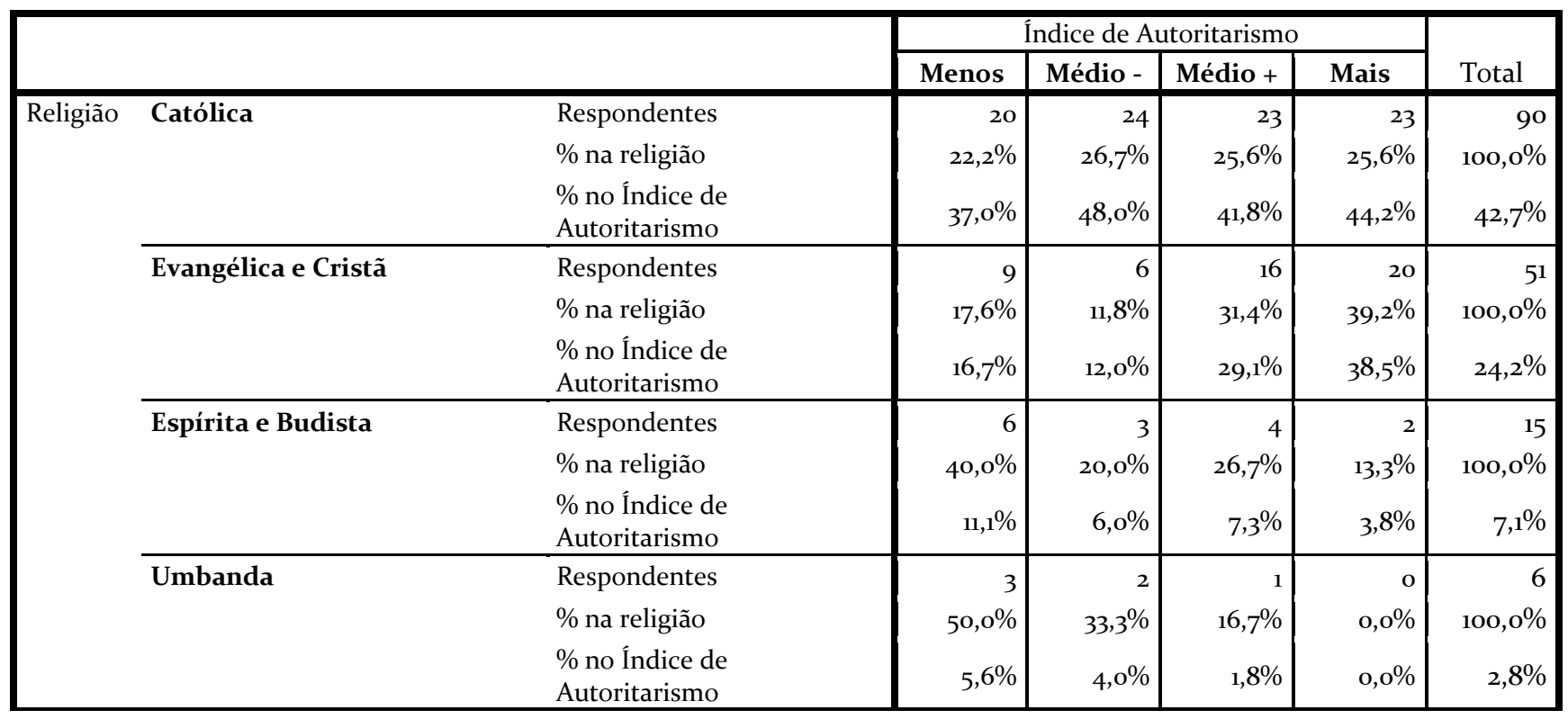




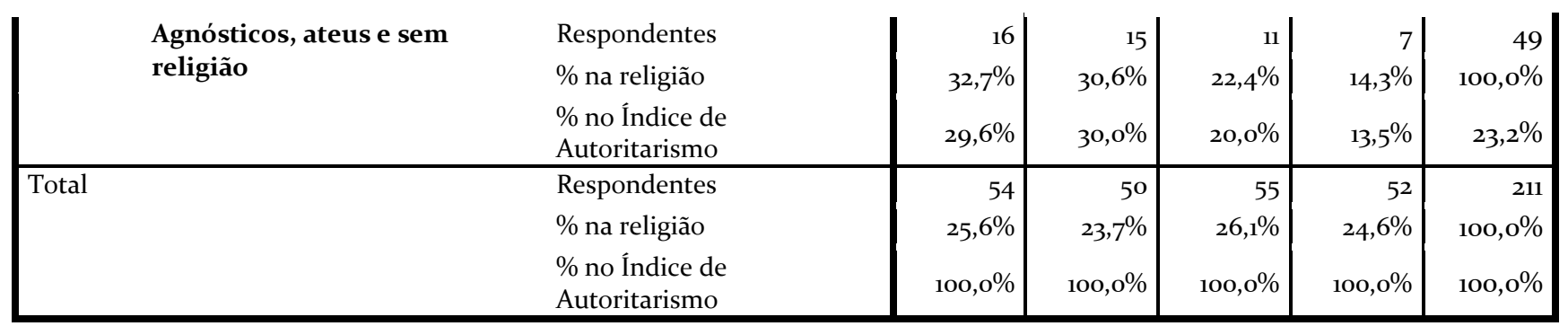

*Significância: 0,072

Podemos notar, na relação entre o índice e a religião dos respondentes, que esta última é uma variável bastante importante na explicação do fenômeno do autoritarismo dentro do universo pesquisado.

Inicialmente, observamos que a maioria da amostra é composta por respondentes católicos (9o alunos ou 42,7\% do universo). A religião católica não pode ser considerada um fator explicativo para o autoritarismo, uma vez que os representantes da mesma se encontram quase igualmente distribuídos entre as quatro categorias do índice, com poucas variações entre uma e outra. Contudo, o mesmo não se passa com as demais religiões ou com aqueles que não possuem uma religião.

Dentre os evangélicos e cristãos, 31,4\% integram a faixa "médio+" autoritários e 39,2\% a faixa "mais" autoritários, de modo que 70,6\% dos respondentes evangélicos estão localizados nos quadrantes mais autoritários da amostra.

Por outro lado, os espíritas, budistas e umbandistas se encontram, majoritariamente, entre os "menos" e os "médio-" autoritários. Em relação aos dois primeiros, $40 \%$ estão na categoria "menos" e $20 \%$ estão na "médio-" e, quanto aos últimos, 50\% estão na categoria "menos" e 33,3\% na "médio-". Ressalto que os umbandistas não têm nenhum representante na categoria "mais" autoritários.

Na mesma linha seguem os respondentes agnósticos, ateus ou sem religião, de maneira que também estão concentrados, em sua maioria, nas categorias "menos" (32,7\%) e "médio-" (30,6\%) autoritários.

Podemos perceber, portanto, que o fato de pertencer à religião evangélica é um dos fatores explicativos do perfil autoritário e conservador dos respondentes dentro do universo pesquisado. 
Para uma compreensão mais ampla do fenômeno dentro do universo pesquisado, julgo importante, também, observar a relação existente entre as escolas e a religião dos alunos (Quadro 12):

\section{Quadro 12 - Escolas x Religião dos Alunos}

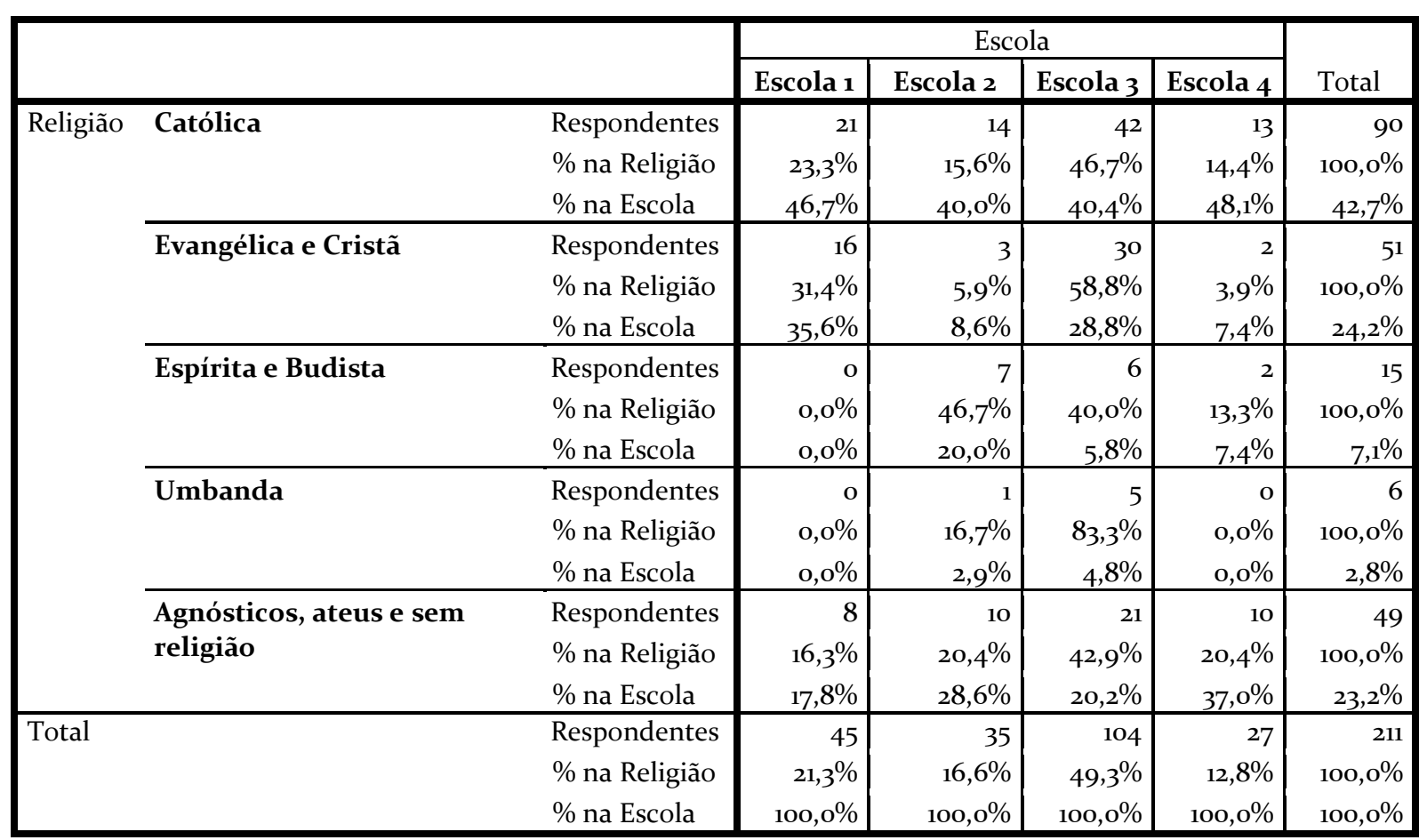

*Significância: o,004

Novamente, a distribuição de católicos é quase uniforme nas quatro escolas. Quanto aos evangélicos, podemos notar que eles se concentram, majoritariamente, nas escolas públicas, estando, contudo, em maior número na Escola 1 (35,6\%) do que na Escola 3 (28,8\%). Ademais, considerando-se todos os respondentes que se declararam evangélicos, 31,4\% estão na Escola 1 e 58,8\% estão na Escola 3.

Os espíritas e budistas encontram sua maior representação na Escola 2, de modo que $20 \%$ dos respondentes desta escola são espíritas ou budistas e 46,7\% dos respondentes espíritas e budistas se concentram nela, que é a mais homogênea entre as particulares. 
O número de respondentes agnósticos, ateus ou sem religião é maior, em termos proporcionais, nas escolas particulares. Na Escola 2, 28,6\% dos participantes se enquadram nessa categoria, enquanto, na Escola 4, eles são 37\%.

Podemos inferir, portanto, que a variável religião possui uma relação com a classe social a que pertencem os respondentes, uma vez que os evangélicos se localizam, sobretudo, nas escolas mais populares, e os espíritas, budistas e sem religião, nas escolas de classe média. Tais resultados corroboram os já acima apresentados, uma vez que os mesmos apontam uma relação direta entre menor renda, religião evangélica e maior autoritarismo/conservadorismo.

Passemos, agora, para a correlação da variável "índice de autoritarismo” com a variável “candidatos à presidência da república em 201817” (Quadro 13).

\section{Quadro 13 - Índice de Autoritarismo x Candidatos à Presidência em 2018 (209 respondentes)}

\begin{tabular}{|c|c|c|c|c|c|c|c|}
\hline & & & \multicolumn{4}{|c|}{ Índice de Autoritarismo } & \multirow[b]{2}{*}{ Total } \\
\hline & & & Menos & Médio - & Médio + & Mais & \\
\hline \multirow[t]{18}{*}{ Candidatos } & Marina Silva & Respondentes & $\mathrm{o}$ & 1 & 3 & & 7 \\
\hline & & $\%$ nos Candidatos & $0,0 \%$ & $14,3 \%$ & $42,9 \%$ & $42,9 \%$ & $100,0 \%$ \\
\hline & & $\begin{array}{l}\text { \% no Índice de } \\
\text { Autoritarismo }\end{array}$ & $0,0 \%$ & $2,0 \%$ & $5,6 \%$ & $5,8 \%$ & $3,3 \%$ \\
\hline & Ciro Gomes & Respondentes & & 20 & & & \\
\hline & & $\%$ nos Candidatos & $38,0 \%$ & $28,2 \%$ & $21,1 \%$ & $12,7 \%$ & $100,0 \%$ \\
\hline & & $\begin{array}{l}\text { \% no Índice de } \\
\text { Autoritarismo }\end{array}$ & $50,0 \%$ & $40,8 \%$ & $27,8 \%$ & $17,3 \%$ & $34,0 \%$ \\
\hline & Fernando Haddad & Respondentes & 12 & 5 & 9 & & 32 \\
\hline & & $\%$ nos Candidatos & $37,5 \%$ & $15,6 \%$ & $28,1 \%$ & $18,8 \%$ & $100,0 \%$ \\
\hline & & $\begin{array}{l}\text { \% no Índice de } \\
\text { Autoritarismo }\end{array}$ & $22,2 \%$ & $10,2 \%$ & $16,7 \%$ & $11,5 \%$ & $15,3 \%$ \\
\hline & Jair Bolsonaro & Respondentes & & & & & \\
\hline & & $\%$ nos Candidatos & $0,0 \%$ & $3,8 \%$ & $26,9 \%$ & $69,2 \%$ & $100,0 \%$ \\
\hline & & $\begin{array}{l}\text { \% no Índice de } \\
\text { Autoritarismo }\end{array}$ & $0,0 \%$ & $2,0 \%$ & $13,0 \%$ & $34,6 \%$ & $12,4 \%$ \\
\hline & Álvaro Dias & Respondentes & o & & o & & 1 \\
\hline & & $\%$ nos Candidatos & $0,0 \%$ & $100,0 \%$ & $0,0 \%$ & $0,0 \%$ & $100,0 \%$ \\
\hline & & $\begin{array}{l}\% \text { no Índice de } \\
\text { Autoritarismo }\end{array}$ & $0,0 \%$ & $2,0 \%$ & $0,0 \%$ & $0,0 \%$ & $0,5 \%$ \\
\hline & Guilherme Boulos & Respondentes & 5 & 4 & o & o & 9 \\
\hline & & $\%$ nos Candidatos & $55,6 \%$ & $44,4 \%$ & $0,0 \%$ & $0,0 \%$ & $100,0 \%$ \\
\hline & & $\begin{array}{l}\% \text { no Índice de } \\
\text { Autoritarismo }\end{array}$ & $9,3 \%$ & $8,2 \%$ & $0,0 \%$ & $\mathrm{o}, \mathrm{o} \%$ & $4,3 \%$ \\
\hline
\end{tabular}

17 Apesar de o nome de todos os candidatos à presidência da República constarem no questionário aplicado, os resultados serão exibidos apenas para aqueles que foram citados pelos respondentes. 


\begin{tabular}{|c|c|c|c|c|c|c|c|}
\hline & Cabo Daciolo & $\begin{array}{l}\text { Respondentes } \\
\% \text { nos Candidatos } \\
\% \text { no Índice de } \\
\text { Autoritarismo }\end{array}$ & $\begin{array}{r}0 \\
0,0 \% \\
\text { o,o\% }\end{array}$ & \begin{tabular}{r|}
2 \\
$100,0 \%$ \\
$4,1 \%$
\end{tabular} & $\begin{array}{r}0 \\
0,0 \% \\
0,0 \%\end{array}$ & $\begin{array}{r}0 \\
0,0 \% \\
0,0 \%\end{array}$ & $\begin{array}{r}2 \\
100,0 \% \\
1,0 \%\end{array}$ \\
\hline & João Amoêdo & $\begin{array}{l}\text { Respondentes } \\
\text { \% nos Candidatos } \\
\text { \% no Îndice de } \\
\text { Autoritarismo }\end{array}$ & $\begin{array}{r}0 \\
0,0 \% \\
0,0 \%\end{array}$ & \begin{tabular}{r|}
2 \\
$28,6 \%$ \\
$4,1 \%$
\end{tabular} & $\begin{array}{r}0 \\
0,0 \% \\
0,0 \%\end{array}$ & $\begin{array}{r}5 \\
71,4 \% \\
9,6 \%\end{array}$ & $\begin{array}{r}7 \\
100,0 \% \\
3,3 \%\end{array}$ \\
\hline & Não vou votar & $\begin{array}{l}\text { Respondentes } \\
\text { \% nos Candidatos } \\
\text { \% no Índice de } \\
\text { Autoritarismo }\end{array}$ & $\begin{array}{r}10 \\
18,5 \% \\
18,5 \%\end{array}$ & $\begin{array}{r}13 \\
24,1 \% \\
26,5 \%\end{array}$ & $\begin{array}{r}20 \\
37,0 \% \\
37,0 \%\end{array}$ & $\begin{array}{r}11 \\
20,4 \% \\
21,2 \%\end{array}$ & $\begin{array}{r}54 \\
100,0 \% \\
25,8 \%\end{array}$ \\
\hline Total & & $\begin{array}{l}\text { Respondentes } \\
\% \text { nos Candidatos } \\
\text { \% no Índice de } \\
\text { Autoritarismo }\end{array}$ & $\begin{array}{r}54 \\
25,8 \% \\
100,0 \%\end{array}$ & $\begin{array}{r}49 \\
23,4 \% \\
100,0 \%\end{array}$ & $\begin{array}{r}54 \\
25,8 \% \\
100,0 \%\end{array}$ & $\begin{array}{r}52 \\
24,9 \% \\
100,0 \%\end{array}$ & $\begin{array}{r}209 \\
100,0 \% \\
100,0 \%\end{array}$ \\
\hline
\end{tabular}

*Significância: o,ooo

Podemos notar que os respondentes localizados nas categorias "menos" e "médio-autoritários indicaram voto, majoritariamente, em candidatos posicionados politicamente mais à esquerda. Nesse sentido, considerando a soma das porcentagens, estão concentrados nas duas primeiras faixas: $66,2 \%$ dos que disseram que votariam em Ciro Gomes, 53,1\% dos que votariam em Fernando Haddad e 100\% dos que votariam em Guilherme Boulos (nenhum dos respondentes que indicou voto em Boulos está posicionado nas categorias “médio+" ou “mais”).

Por outro lado, candidatos posicionados politicamente mais à direita foram indicados por respondentes enquadrados, sobretudo, nas categorias "médio+" e "mais" autoritários. Nesse aspecto, considerando novamente a soma das porcentagens, estão localizados nas duas últimas categorias: 96,1\% dos que votariam em Jair Bolsonaro e $71,4 \%$ dos que votariam em João Amoedo. Marina Silva, que aqui estou considerando ser de "centro-direita”, também concentrou votos de respondentes localizados nas faixas "médio+" e "mais" (85,8\%).

Por fim, observamos que a maioria dos respondentes que marcaram a opção "não vou votar", a qual poderia ser escolhida caso o participante ainda não tivesse título pela não obrigatoriedade em razão da idade ou se fosse votar nulo ou em branco, está concentrada nas categorias "médio+" e "mais", totalizando 57,4\%. Este fato indica uma relação direta entre despolitização e maiores níveis de autoritarismo/conservadorismo dentro do universo pesquisado. 
Ademais, podemos notar, também (Quadro 14), que o maior número de participantes que selecionaram esta opção está nas escolas públicas - 43,6\% na Escola 1 e 46,3\% na Escola 3, sendo que, na Escola 1, 54,3\% dos respondentes do questionário indicaram que não iriam votar, o que demonstra que também existe uma relação direta entre as classes populares e uma maior despolitização.

\section{Quadro 14 - Escolas x Candidatos à Presidência em 2018 (209 respondentes)}

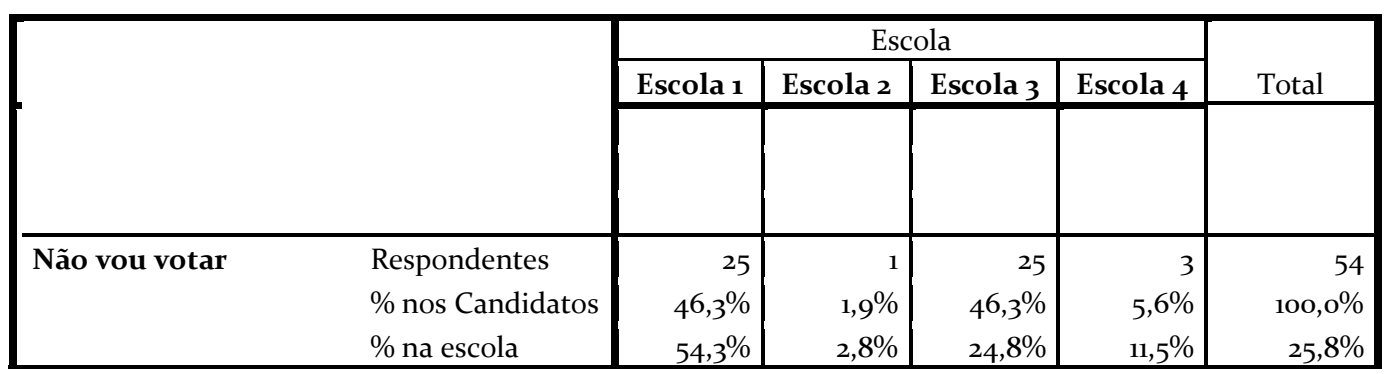

*Significância: o,ooo

Estes resultados estão bastante coerentes em termos do que se poderia esperar dos respondentes que tem posições políticas mais à esquerda, os quais tendem a ser mais progressistas e menos conservadores, e dos respondentes que tem posições políticas mais à direita, a qual pode assumir, dentre as suas variadas vertentes, um caráter mais conservador moralmente e mais autoritário politicamente, sobretudo no que toca aos papéis punitivo e repressor do Estado.

Vejamos, por fim, a correlação entre o "índice de autoritarismo" e as escolas participantes da pesquisa (Quadro 15). 
Quadro 15 - Índice de Autoritarismo x Escolas (214 respondentes)

\begin{tabular}{|c|c|c|c|c|c|c|c|}
\hline & & & \multicolumn{4}{|c|}{ Índice de Autoritarismo } & \multirow[b]{2}{*}{ Total } \\
\hline & & & Menos & Médio - & Médio + & Mais & \\
\hline \multirow[t]{12}{*}{ Escola } & Escola 1 & Respondentes & 9 & 11 & 10 & 17 & \\
\hline & & $\%$ na escola & $19,1 \%$ & $23,4 \%$ & $21,3 \%$ & $36,2 \%$ & $100,0 \%$ \\
\hline & & $\begin{array}{l}\% \text { no Índice de } \\
\text { Autoritarismo }\end{array}$ & $16,4 \%$ & $21,2 \%$ & $18,2 \%$ & $32,7 \%$ & $22,0 \%$ \\
\hline & Escola 2 & Respondentes & 12 & 15 & 7 & 2 & \\
\hline & & $\%$ na escola & $33,3 \%$ & $41,7 \%$ & $19,4 \%$ & $5,6 \%$ & $100,0 \%$ \\
\hline & & $\begin{array}{l}\% \text { no Índice de } \\
\text { Autoritarismo }\end{array}$ & $21,8 \%$ & $28,8 \%$ & $12,7 \%$ & $3,8 \%$ & $16,8 \%$ \\
\hline & Escola 3 & Respondentes & 26 & 20 & & 28 & 104 \\
\hline & & $\%$ na escola & $25,0 \%$ & $19,2 \%$ & $28,8 \%$ & $26,9 \%$ & $100,0 \%$ \\
\hline & & $\begin{array}{l}\% \text { no Índice de } \\
\text { Autoritarismo }\end{array}$ & $47,3 \%$ & $38,5 \%$ & $54,5 \%$ & $53,8 \%$ & $48,6 \%$ \\
\hline & Escola 4 & Respondentes & 8 & 6 & 8 & 5 & \\
\hline & & $\%$ na escola & $29,6 \%$ & $22,2 \%$ & $29,6 \%$ & $18,5 \%$ & $100,0 \%$ \\
\hline & & $\begin{array}{l}\% \text { no Índice de } \\
\text { Autoritarismo }\end{array}$ & $14,5 \%$ & $11,5 \%$ & $14,5 \%$ & $9,6 \%$ & $12,6 \%$ \\
\hline \multirow[t]{3}{*}{ Total } & & Respondentes & 55 & 52 & & 52 & 214 \\
\hline & & $\%$ na escola & $25,7 \%$ & $24,3 \%$ & $25,7 \%$ & $24,3 \%$ & $100,0 \%$ \\
\hline & & $\begin{array}{l}\% \text { no Índice de } \\
\text { Autoritarismo }\end{array}$ & $100,0 \%$ & $100,0 \%$ & $100,0 \%$ & $100,0 \%$ & $100,0 \%$ \\
\hline
\end{tabular}

*Significância: 0,042

No que toca à relação entre o índice de autoritarismo e as escolas pesquisadas, observamos que a Escola 1 e a Escola 3 (escolas públicas) são as que concentram o maior número de respondentes, considerando o total do universo, que estão enquadrados nas categorias "médio+" e "mais" - 72,7\% e 86,5\%, respectivamente, contra $27,2 \%$ (médio+) e 13,4\% (mais), porcentagens das escolas particulares.

Analisando-se cada escola em separado, o que é importante em razão das peculiaridades de cada uma, podemos notar que a Escola 1 (pública) é a que possui mais alunos participantes enquadrados na categoria "mais" autoritarismo.

A Escola 3 (pública) apresenta uma distribuição que pouco varia entre as quatro categorias, possuindo um maior número de alunos (mesmo que com uma diferença pouco expressiva em relação às demais faixas) concentrados na categoria "médio+", 28,8\%. Acredito que esta baixa variação é devida ao caráter heterogêneo da escola, já descrito anteriormente.

A Escola 2 (particular) é que possui mais alunos participantes englobados pelas categorias "menos" e "médio-" - 33,3\% e 41,7\%, respectivamente, sendo a escola menos autoritária/conservadora de toda a amostra. 
A Escola 4 (particular) também se mostrou mais heterogênea em relação à Escola 2, razão pela qual acredito que se justifica a sua distribuição quase uniforme de alunos pelas categorias, de forma semelhante à Escola 3 (pública). Demonstra o seu caráter heterogêneo o fato de que, nesta escola, a mesma porcentagem de alunos (29,6\%) está enquadrada nas categorias "menos" e "médio+".

A relação entre as escolas o índice de autoritarismo corrobora os resultados acima apresentados, no sentido de uma maior tendência de serem as classes mais populares a adotar, dentro do universo pesquisado, posições políticas e morais de cunho mais autoritário/conservador.

\section{Considerações Finais}

Os resultados apresentados neste trabalho corroboram, portanto, a hipótese principal de que os capitais (econômico, cultural e social) acumulados pelos indivíduos estudados, na medida em que se apresentem em maior ou menor grau, possuem uma relação direta com o fato de eles revelarem ou não tendências a adotar posições autoritárias, conservadoras ou reacionárias.

Nesse sentido, pude observar que as camadas populares do universo pesquisado, ou seja, as que possuem menores níveis acumulados de capital, são as que mais aderem a essa posição. Os dados apontam que tais camadas são as mais autoritárias/conservadoras e, ao mesmo tempo, as mais despolitizadas, além de possuírem forte viés religioso, sobretudo evangélico.

Em sentido contrário, as classes médias deste universo, concentradas, sobretudo, nas escolas particulares e, de modo ainda mais específico, na Escola 2, são as que apresentam uma menor tendência à adesão a posições políticas e morais autoritárias/conservadoras, além de serem mais politizadas.

Concluí, portanto, que existe um habitus autoritário nas camadas populares integrantes do universo pesquisado, fato ausente nas suas classes médias. Nesse sentido, podemos afirmar que a classe social, conceituada, aqui, em termos bourdieusianos, é um fator altamente explicativo do fenômeno do autoritarismo neste universo. 
Referências

ADORNO, T. W., et al. Etudes sur la personnalité autoritaire. Paris: Editions Allia, 2007.

BOURDIEU, Pierre. A Distinção: crítica social do julgamento. Porto Alegre, RS: Zouk, 2015 .

FERNANDES, Dmitri Cerboncini; MESSENBERG, Debora. Um espectro ronda o Brasil (à direita). Plural, v. 25, n.1, 2018.

MANNHEIM, Karl. O significado do conservantismo. In FORACCHI, Marialice Mencarini (Org.). Karl Mannheim. São Paulo: Ática, 1982. 